\title{
How did Public Buildings and Monuments Contribute to the Evolution of Agora to Forum during the Early Roman Period in Athens?
}

\begin{abstract}
Han Xiao*
Cultural Heritage Management, Archaeology Department, University of Sheffield, South Yorkshire, Sheffield S1 3NJ, UK

*Corresponding author: Han Xiao, xhhh1996@163.com

Abstract: This article uses Athens in the early Roman Empire, the province of Achaia, and the political culture behind it as a research environment. Then focuses on two public spaces in Athens: Classic Agora and Roman Forum, which are used as cases to research the relationships between these public spaces. Based on the dynamic evolution of public buildings, monuments, and new public spaces in Athens during that period, this article explores the reasons for this adaptation and transformation of the Forum to Agora in the Roman period. Research suggests that the construction and existence of public buildings and monuments in Athens during the Roman period may have played a major role in promoting this transition from Agora to Forum.
\end{abstract}

Keywords: Public Space; Greek Agora; Roman Forum

Publication date: July 2021; Online publication: July 31, 2021

\section{Introduction}

When studying the historical public spaces, people always easily compare the ancient Greek agora with the ancient Roman forums, which is the classic of public spaces in these two great civilizations. Agora and Forum are not the same in the retrospective origin, but there are some reliable links between them. The origin of Forum, first appeared in The Law of Twelve Tables, describing the sepulchral vestibule. In the early days of the Roman Republic, it meant the flat, formerly swampy space between the Palatine and Capitoline hills, where public meetings could not be held in the Capitoline area ${ }^{[1]}$. After developed over centuries, it evolved to describe the public square, which was the area where the religious, political, and social activities of the Roman Empire took place. The term Agora, first appeared in Homer's works, which means where people gather or the surrounding environment where they gather. After gradual development, it became synonymous with an area in ancient Greek cities ${ }^{[2]}$. Free-born citizens in the city can gather here to listen to municipal radio, conducting and discussing military and political activities ${ }^{[3]}$. In the 5th century BC, the term was explicitly used to describe Greece urban core areas, where citizens' religious beliefs, political assemblies, judicial trials, social contacts, commercial contacts, and other activities took place. There is an inevitable connection between Agora and Forum due to the integration of Roman culture to a certain extent. Encyclopedia Britannica described it as an orderly spatial adaptation of Greek agora and the Acropolis in the Forum description ${ }^{[4]}$. This article attempts to speculate on the relationship and evolution of these two public spaces. The author uses Athens, the province of Achaia and its political culture in the early Roman Empire as the necessary study background, focusing on the wax and wane of the Ancient Agora of Athens. Through research and analysis, exploring the reasons for the adaptation and transformation of the agora to the forum. The author believes that the construction and existence of public 
buildings and monuments in Athens during the Roman period may have contributed to the transition from Agora to Forum.

\section{Early Roman Empire and The Classic Agora at Athens}

\subsection{Roman Empire, Hellenistic Civilization, the Province of Achaia}

Rather than describing that the Roman Empire Romanizing Athens during that period, one can also think that the Romans absorbed the high civilization from the Hellenistic culture. As people familiar, the ancient Greek peaked in every field of human civilization in the classical era. Whether art, architecture or natural science, all these subjects were thriving, and establishing a democratic system gave birth to great philosophical ideas in the agora. Alexander the Great (356-323 BC) inherited his father's last wish and invaded Persia in an all-around way to avenge Persia's invasion of Greece in 480 BC. In the process, he was directed by Plato's great student Aristotle, spreading the Hellenistic civilizations to every place he had contacted $^{[5]}$. Therefore, the ancient Romans felt the cultural influence early from Greek. They realized that they could benefit from a more prosperous and more mature civilization, hence made them stronger after long-term gains, which directly led to the annexation of Macedonia (168 BC), the Greek mainland (146 BC), the Kingdom of Pergamum (133 BC), and the entire Hellenized East finally. In addition to the Greek language, they absorbed the structure and technology from Hellenistic culture and further developed it with fantastic adaptability. From 119 or 118 BC, those who were not satisfied with studying Greek culture in Rome, local areas began to enter the Ephebic College for study at Athens ${ }^{[6]}$.

In 146 BC, the Roman general Lucius Mummius captured and destroyed the Achaean league with Collins as its capital. This league is like a federal state consisting of twelve cities, and each participating city remains independent in internal affairs. Around $31 \mathrm{BC}$, it was separated from the province of Macedonia during the reign of Emperor Augustus, and on this basis, it became independent as Achaea Province, also known as Achaia Province. Geographically, it consists of the Peloponnese, central and eastern Greece, and parts of Thessaly, equivalent to southern Greece today roughly. Morley believes that the Augustus era's provincial system allowed the culture to be subtly integrated ${ }^{[7]}$; the imperial system paid more attention to establishing a standard order, common law and supreme monarch while respecting cultural diversity. The province of Achaea, where Athens is located, is senatorial in political management, so it does not station a large military. Some cities in Achaea, such as Athens and Sparta, are still allowed to maintain autonomy on their territory, with no destructive lifestyle changes. At the same time, due to Athens's highly prosperous education system, it became the cultural center for the Roman elite to receive education, and it was one of the most important cities in the cultural education of the Empire. As Horace said: "Greece captured the savage victor (Graecia Capta Ferum Victorem Cepit) ${ }^{[8]}$." Morley also believes that the Rome provincial system is conducive to the spread of civilization, and at the same time, it can strengthen the colony's sense of identity with the Empire through this system ${ }^{[9]}$. Until the late classical age, Achaia was a relatively prosperous and peaceful area of the ancient Roman Empire.

\subsection{The Classic Agora of Athens during ancient Greece}

In this context, if people want to understand some reasons or relationships that pushed the forum to transform from the agora, they need first to understand the Agora's architectural performance in ancient Greece. A city's Agora is mainly located in the urban center or near the port in a geographic location. The sense of boundary consists of public buildings, temples, or sometimes colonnades containing shops or stoa. At the same time, statues, altars, fountains, trees also will be embellished and decorated in the space. It is generally square or rectangular from the shape, but its shape is often defined according to the specific function of this area or by the boundary of surrounding functional constructions ${ }^{[10]}$. Although the essential physical elements that constitute an Agora will change with the times and the scale of the city, and the 
political meaning and religious beliefs it contains will also vary, as a public space, its content richness can include "any activity one can imagine: in a sense, the ancient version of the World Wide Web "11]."

As shown in Figure 1., the expression of the Athenian Agora during the Socrates and Plato periods, about the 5th-4th century BC, this Agora was still surrounded by Hellenistic civilization and has not yet been inserted into Roman context. The Classic Agora, located northwest of the Acropolis. At the center of the Agora is the ancient Greek altar ("bômos" in Greek), which enshrines the most representative twelve gods in Greek mythology. The northwest of the altar is four stoas, namely Poikile Stoa, Royal Stoa, and Stoa of Zeus. Poikile Stoa means "Painted Porch" in Greek, which depicts the Athenians' victory in war. Royal Stoa is the Royal Archon (Archon Basileus) seat and includes a copy of the city's laws and the stone sworn by new officials. The Stoa of Zeus is used to commemorate Zeus in recognition of his defeat of the Persians in Plataia. Below it is the Temple of Fatherly Apollo (Apollon Pairóos). The building just at the west of Agora is Hephaistion or Theseion, a temple used for Hephaestus and Athena Ergane, decorated with the daily life events of Hercules and Theseus. The two constructions below are the Bouleuterion, the meeting room of The Five Hundred ("Pentacosiomedimnes"), the left one is new, and the right one is the old Bouleuterion. On their eastern open space is the Monument of the Eponymous Heros, a monument to the same name's heroes from the ten tribes of Athenian democracy. The rotunda is Tholos, which is the residence of the rightful "prytany" in the Athenian democratic system during office. The Strategeion located in the southwest corner is used as a meeting room for the Athenian ten generals. The Agora Stone near it is also the boundary stone of this Agora, marking the entrance. Next to the entrance is "Heliæa," dedicated to Aegina's hero Aiakos, used to display the verdict and later developed into a granary.

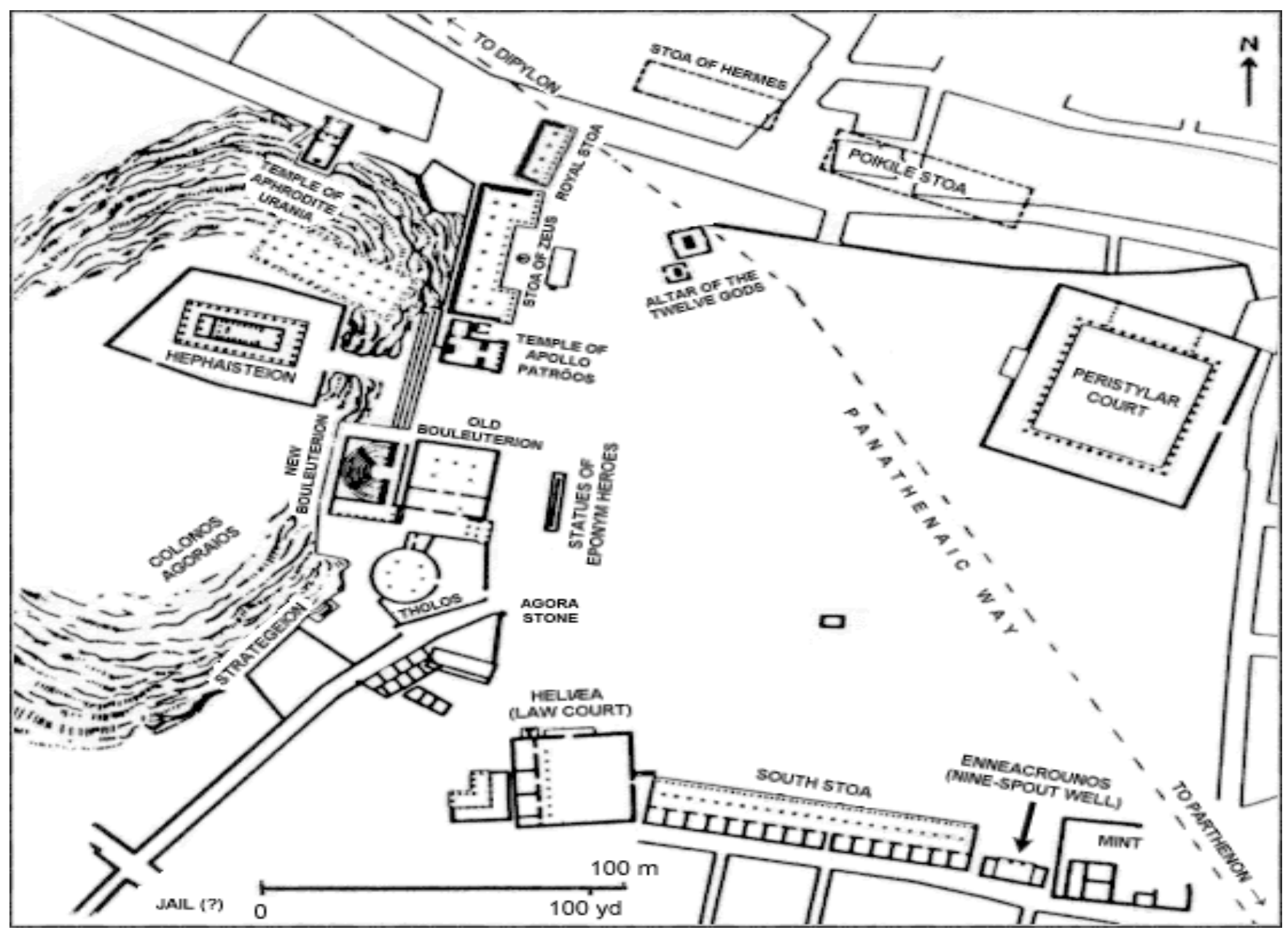

Figure 1. Map of the Agora of Athens in Socrates and Plato's time (Suzanne 1998) ${ }^{[12]}$ 
Similarly, according to some archaeological evidence, there is a Stoa on the south side of the Agora used by officials responsible for public affairs. On the east side of it is Enneacrounos, responsible for water supply, mistaken for a fountain by Pausanias in the 2nd century. At the southeast corner of the Agora is the Mint. In the northeast corner of the Agora, opposite the Mint, is the Peristylar Court, which was the court at the time and had a jury system and surrounded by vendors ${ }^{[13]}$. Through this Agora, fully displayed from the establishment of beliefs in ancient Greek culture-various temples and monuments to functional buildings- the court and the water supply, The Agora in ancient Greece provided various buildings to develop its democracy.

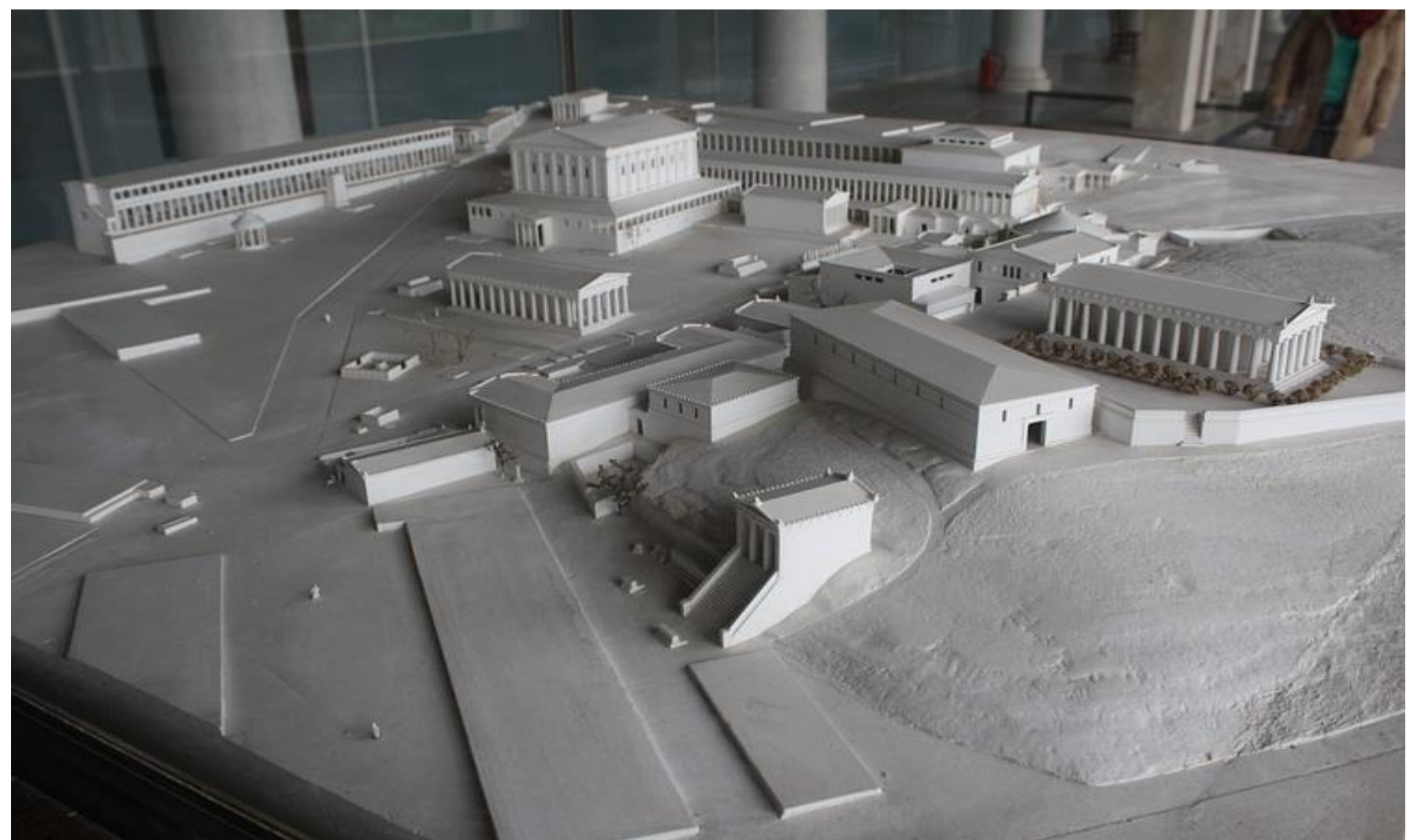

Figure 2. A model of the Agora of Athens at its maximum extension during the 2nd century CE is exhibited in the Athens Agora Museum. ${ }^{[17]}$

\subsection{The Roman Evidence in The Athens Agora}

Everything was traceable in the early Empire. The Romans paid tribute to the Hellenistic civilization through various public buildings and monuments while also implanting their culture and beliefs. Starting from the Augustus period (30-14BCE), the Classic Agora's appearance changed dramatically, leaving marks of the Roman rule (Figure 2.). Augustus the Great ordered the entire classical temple to be relocated from other areas to the Classic Agora in Athens and dedicated to Ares, the god of war in Greek mythology. This behavior was called "Itinerant temples," and it can also be regarded as the scars left by Augustus the Great to repair the Sulla looting of Athens (86BCE) during the Roman Civil War ${ }^{[14]}$. Later, due to the donations of Romans and local nobles, this Agora was filled with various public buildings and statues. Roman general Marcus Vipsanius Agrippa donated the Odeion of Agrippa during his visit to Athens (1614BCE). At the beginning of its construction, it was used as a theatre for musical performances. However, the reducing audience capacity caused by the collapse and reconstruction; hence the Odeion of Agrippa was used for philosophical speeches. In 98-102CE, the Athenian Titus Flavius Pantainos built The Library 
of Pantainos. According to archaeological inscriptions, he and his family dedicated the building to Emperor Trajan, and there was a South-East Stoa to serve this library located on the eastern border. During Emperor Hadrian's reign, more buildings were built in this ancient Agora, such as The Basilica, which is a product of typical Roman culture, used for meetings or commercial trade, and it also has a Nymphaeum, a beautifully carved construction with a water storage function, also used to decorate the classic Agora. Therefore, the statues of this period are also vibrant, mainly the portraits of famous Romans and Athenians. One of the most prominent figures is Emperor Hadrian, and the most beautiful is the head of an old priest of Isis. Although a Greek engraver made this statue, it also reflected Roman and Egyptian techniques and skills ${ }^{[15]}$. According to archaeological evidence, some statues used to worship heresy were erected here during this period ${ }^{[16]}$.

\section{Transformation of The Classic Agora in Athens}

\subsection{Reshaping the Significance of The Classic Agora}

The Hellenistic Agora was a gathering place, and all the activities that took place here were made public. In other words, it requires the participation and witness of citizens, such as displaying the verdict or showing the copy of city laws, which implies that all the citizen needs to abide by the principles of urban policies and regulations. During this period, the commercial activities gave the space vitality and admitted that all citizens had the right to enter this space to a certain extent, demonstrating the spatial nature of democracy. The Altar of the Twelve Gods existed on the people's functional beliefs, and the Monument of the Eponymous Heros was also a typical Athenian democracy. Whether they exist to pray for "asylum" or emphasize the spirit of democracy, there is no worship of the ruling class, rights, and individuals. What cannot be denied is that in the early Roman Empire, this Agora in Athens was continually being destroyed and reshaped.

Nevertheless, at that time, Athens was still a place of artistic and cultural pilgrimage for the Roman elite, so they continue to provide funds to support the "repairing." Some new public buildings and monuments have been built to maintain sacredness and commemorate past flourishing civilizations. However, Alcock ${ }^{[18]}$ believes that this phenomenon is ironic because such a "new" memorial space is very ancient. If people compare the floor plan of this Agora in the 4-5th century BC with the 2nd century AD, they can find that the layout of this place has undergone tremendous changes. The existence of the Odeion of Agrippa marks the entry of leisure and entertainment into this place that once symbolized democracy, the meaning of the Agora had been changed, and it has gradually become an art center and entertainment venue. Those realistic portrait sculptures of characters have also entered this space to commemorate donors or commemorate the royal and nobility. As mentioned earlier, the statue of Emperor Hadrian was built in this Agora. Dickenson ${ }^{[19]}$ believes that the existence of these statues, their placement, and the preserved statues of gods in the ancient Greek period, the connection within them played a function of reshaping memory. These links allow these respectable people who were still alive and shared the urban public space with other gods, heroes and mythical figures and shared the people's memories. Although the injected form seems to be a tribute to past civilizations, it just makes this Agora look more like an antique. Does the imperially ruled Athens still need democracy? No, it does not need, because the Empire has already ruled it.

\subsection{From the Aspect of Architectural Form to The Roman Forum}

As previously mentioned, Athens has always maintained its status as an educational center in the early Empire, and the old "Agora" sacredness must be preserved, which means that it needs to undergo a functional transfer. Due to this old urban heart is full of new temples and new monuments; it is enough to maintain its function used for pilgrimage if it survives. At the end of the first century $\mathrm{BC}$, to ensure enough 
space in the Agora to build new buildings, small shops and houses in the north were demolished. However, how to maintain its commercial functions? It was true that this behavior will result in lacking commercial spaces for the Athenians, so they need a new place. This fact happened simultaneously with the establishment of the nearby Roman Agora ${ }^{[20]}$. This Roman Agora (Figure 3.), located on the north side of the Acropolis, connected to the old one via a paved street. It was proposed by Caesar the Great but was built during the Augustus period. Thus, the Roman Agora in Athens is an extension of the commercial functions of the ancient Agora. According to archaeological evidence, it has been the commercial center of Athens since its completion, and it has been preserved until the Post-Classical era. However, in terms of architectural form, the middle of the site was open-air, surrounded by a colonnade to enclose this area, and it is indeed a closed public space ${ }^{[22]}$. Another thing worth noting is that at the same time, Caesar the Great built a similar enclosed building in Italy, the "Forum" (Figure 4.). From a connection point of view, the Caesar Forum and this new Roman Agora are very similar in construction and structural evolution. The only difference is that the Italian forum's function was more established for public affairs, and this Roman Agora is just a trading center. Therefore, when many scholars talk about it, they also call it a Roman Forum in Athens. After all, if they only talk about architectural form, there is undeniable trace and relationship.

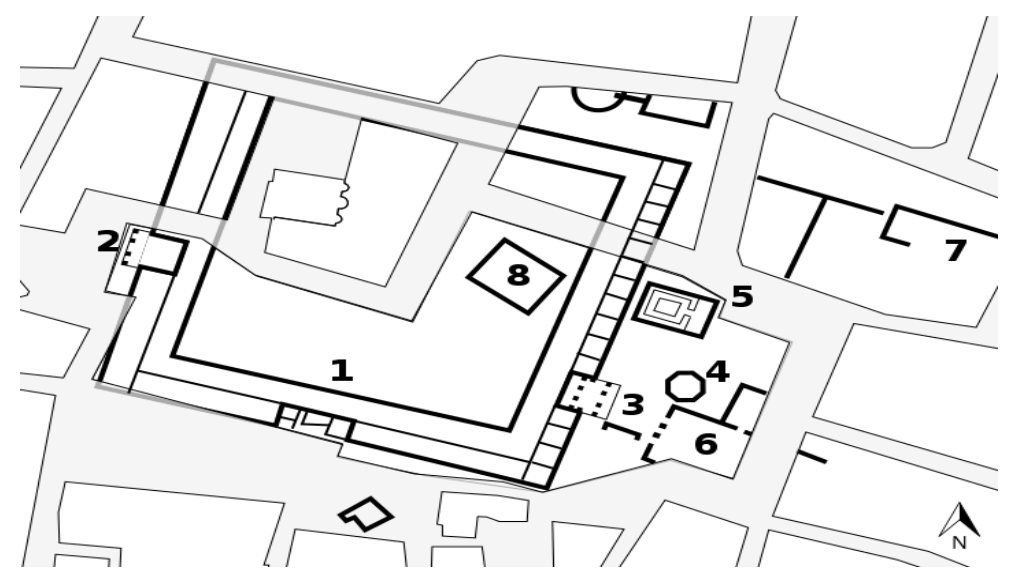
1. Columned agora
2. Gate of Athena Archegetis i.e West Propylon
3. East Propylon
4. Tower of the Winds
5. Vespasianae
6. Agoranomeion
7. Pantheon (exact location not known)
8. Fethiye Mosque

Figure 3. Plan of Roman Agora at Athens [21]

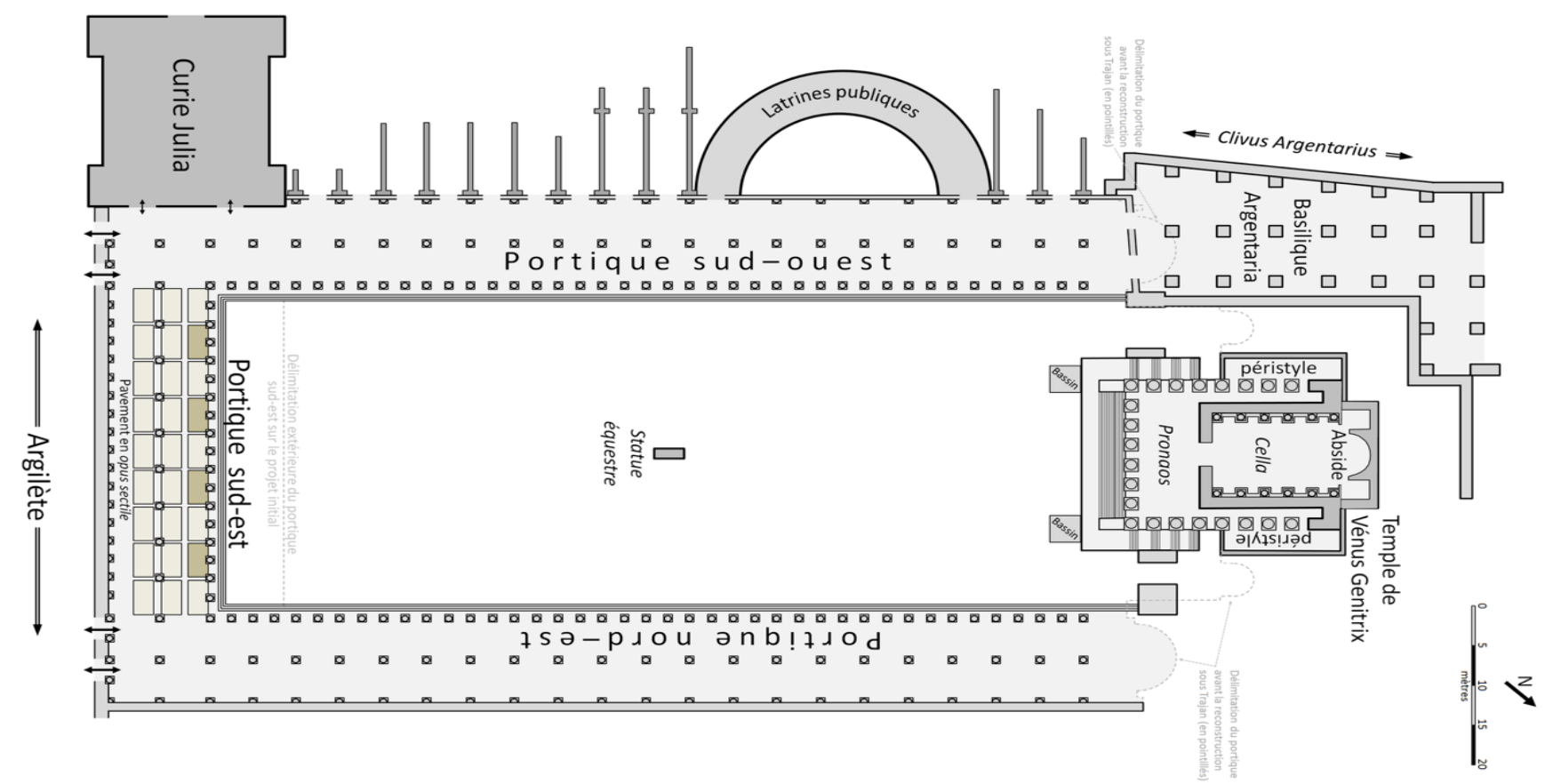

Figure 4. Plan of the Forum of Caesar ${ }^{[23]}$ 


\section{Conclusion}

Alcock believes that these behaviors can be interpreted as the expulsion of commercial activities from its homeland, and the imperial power and class are injected into this site for the classic Agora in Athens ${ }^{\text {[24] }}$ As a result, the site functions experienced dual changes. Based on the early Roman Empire, this article analyses the variations in the classic Agora and its surroundings in Athens during that period and believes that establishing these new public buildings and monuments led to the transformation of the Agora at Athens to a large extent. Specifically, this transformation can be called "from the Agora to the Forum" in architectural performance. In other words, if people talk about the new public building built by Caesar and Augustus, can it be called The Agora? The author is skeptical of calling it Roman Agora because it has lost the democracy that emerged from the Agora. Likewise, can it be called The Forum in Athens? It seems that it has not become a classic Roman Forum, a public space with a similar architectural form.

To some extent, it is more like a complex part of the function of "Agora" and the architectural expression of "Forum." Nevertheless, its archaeological research and excavation work has not been wholly completed. Therefore, the author hopes that people can find a clear answer to the link between "Agora" and "Forum" from future archaeological work.

\section{Disclosure statement}

The author declares no conflict of interest.

\section{References}

[1] Dewitt N, 1919, The Origin of the Roman Forum. The Classical Journal, [online]. 14(7):433-440. Available from: https://www.jstor.org/stable/3287964

[2] Wycherley R, 1942, The Ionian Agora. The Journal of Hellenic Studies, 62:21-32.

[3] Mark J, 2009, Agora. [online]. Ancient History Encyclopedia. Available from: https://www.ancient.eu/agora/

[4] Encyclopedia Britannica, 2016, Forum | Ancient Roman Public Area. [online]. Encyclopedia Britannica. Available from: https://www.britannica.com/topic/forum-ancient-Rome

[5] Mark J, 2013, Ancient Greece. [online]. Ancient History Encyclopedia. Available from: https://www.ancient.eu/greece/

[6] Lauwerys J, et al., 2020, Education: Roman Adoption of Hellenistic Education. [online] Encyclopedia Britannica. Available from: https://www.britannica.com/topic/education/Romanadoption-of-Hellenistic-education

[7] Morley N, 2010, They Called it "Civilization:" The Dynamics of Cultural Change. In The Roman Empire: Roots of Imperialism, Pluto Press, London; New York, 102-127, doi: 10.2307/j.ctt183pb5x.9

[8] Rudd N, ed., 2010, Horace: Epistles Book II and Epistle to the Pisones (“Ars Poetica”): Epistles Book II and Ars Poetica. Cambridge University Press.

[9] Encyclopedia Britannica, 2017, Agora | Definition, History, \& Facts. [online]. Encyclopedia Britannica. Available from: https://www.britannica.com/topic/agora

[10] Donati JC, 2018, The Greek Agora in the Hellenistic and Roman periods: The State of Affairs on the Greek Mainland. Journal of Roman Archaeology, 31:893-906.

[11] Suzanne B, 1998, Map of the Agora of Athens in Socrates and Plato's time. [image]. Available from: 
https://www.plato-dialogues.org/plato.htm

[12] Sakoulas T, nd., History of the Athenian Agora. [online]. Ancient-greece.org. Available from: https://ancient-greece.org/history/agora.html

[13] American School of Classical Studies, nd., Guide. [online]. Agathe.Gr. Available from: http://agathe.gr/guide/

[14] Foundation of The Hellenic World (C2006. History - Archaeology > Roman Period > Findings. [online]. Virtual Reality Digital Collection "The Ancient Agora of Athens". Available from: http://project.athens-agora.gr/index.php?view=per\&pid=7\&lang_id=en

[15] Alcock SE, 2002, Archaeologies of the Greek Past: Landscape, Monuments, and Memories, Cambridge University Press, Cambridge.

[16] Cartwright, M., (2016). A Model of the Agora of Athens at its Maximum Extension During the 2nd Century $\mathrm{CE}$ is Exhibited in the Athens Agora Museum. [image]. Available from: https://www.ancient.eu/image/4519/model-of-the-agora-of-athens/

[17] Dickenson, C., (2017). Public Statues as a Strategy of Remembering in Early Imperial Messene. In: T. Dijkstra, I. Kuin, M. Moser and D. Weidgenannt, ed., Strategies of Remembering in Greece under Rome (100 BC - 100 AD). Sidestone Press, Leiden, 126-142.

[18] Choremi, A, 2017, The Roman Agora: The First Commercial Center of Athens. [online] Brewminate. Available from: https://brewminate.com/the-roman-agora-the-first-commercialcenter-of-athens/

[19] Tomisti, 2016, The Plan of Roman Agora at Athens. [image]. Available from: https://en.wikipedia.org/wiki/File:Plan_Roman_Agora_at_Athens.svg

[20] Hoff, M., (1989). THE Early History of The Roman Agora at Athens. Bulletin Supplement (University of London. Institute of Classical Studies), (55):1-8.

[21] Ahenobarbus C, 2013, Plan of the Forum of Caesar. [image]. Available from: https://en.wikipedia.org/wiki/File:Plan_Roman_Agora_at_Athens.svg 